Applied Physiology, Nutrition, and Metabolism

Canadian Science Publishing Physiologie appliquée, nutrition et métabolisme

\title{
Mechanism Underlying Methyl Eugenol Attenuation of Intestinal Ischemia/Reperfusion Injury
}

\begin{tabular}{|r|l|}
\hline Journal: & Applied Physiology, Nutrition, and Metabolism \\
\hline Manuscript ID & apnm-2017-0043.R1 \\
\hline Manuscript Type: & Article \\
\hline Date Submitted by the Author: & 27-Apr-2017 \\
\hline $\begin{array}{r}\text { Complete List of Authors: } \\
\text { Is the invited manuscript for } \\
\text { consideration in a Special } \\
\text { Issue? : }\end{array}$ & $\begin{array}{l}\text { Saleh, Hanan; Faculty of Science, Cairo University, Zoology department } \\
\text { El-Shorbagy, Haidan; Faculty of Science, Cairo University }\end{array}$ \\
\hline Keyword: & $\begin{array}{l}\text { Methyl eugenol, TNF-a, oxidative stress, intestinal ischemia reperfusion, } \\
\text { Caspase-3 }\end{array}$ \\
\hline \multicolumn{2}{|c}{} \\
\hline
\end{tabular}




\title{
Mechanism Underlying Methyl Eugenol Attenuation of Intestinal Ischemia/Reperfusion Injury
}

\author{
"Hanan Saleh* and "Haidan M. El-Shorbagy \\ Zoology Department, Faculty of Science, Cairo University, Giza 12631, Egypt, \\ *Email: hebead@sci.cu.edu.eg
}

\author{
Short Title: Methyl Eugenol attenuates intestinal I/R injury \\ Dr. Hanan Mohamed Ebead Saleh *Corresponding author (H Saleh) \\ Assistant professor of Physiology at Zoology Department, Faculty of Science, \\ Cairo University, Giza, Egypt. \\ E-mail: hebead@sci.cu.edu.eg / hanan_ebead@yahoo.com
}

Tel: +20 1110121666

Dr. Haidan Mostafa El-Shorbagy

Lecturer of Molecular Biology at Zoology Department, Faculty of Science

Cairo University, Giza, Egypt.

Email: haidan@sci.cu.edu.eg.

These authors contributed equally to this work 


\begin{abstract}
Intestinal Ischemia/Reperfusion injury $(\mathrm{I} / \mathrm{R})$ is associated with a high risk of mortality in the clinical situation. Many factors are involved in I/R including reactive oxygen species (ROS), cytokine release and apoptosis. We aimed to determine whether a pure methyl eugenol (ME) given before intestinal ischemia, protects against intestinal $\mathrm{I} / \mathrm{R}$ and the possible mechanism involved in this protection. Rat received ME $(100 \mathrm{mg} / \mathrm{kg})$ for 30 days then underwent intestinal I/R with $30 \mathrm{~min}$ ischemia and $60 \mathrm{~min}$ reperfusion. Serum lactate dehydrogenase (LDH) level, tissue malondialdehyde (MDA) as well as some antioxidant biomarkers were assessed, while the serum level of tumor necrosis factor alpha (TNF- $\alpha$ ) was determined by ELISA. The change in $T N F-\alpha$ and interleukin 6 (IL-6) gene expressions were evaluated and confirmed by assessing protein level of TNF- $\alpha$ in the intestinal tissue by immunohistochemistry. Apoptosis was evaluated using DNA-laddering assay and by detecting caspase-3 immunohistochemically. Administration of $\mathrm{ME}$ prior to $\mathrm{I} / \mathrm{R}$ injury resulted in a modulation of the production of MDA, $\mathrm{LDH}$, and nitric oxide (NO) and restoration of the tested oxidative stress biomarkers. Pretreatment with ME down-regulated mRNA of TNF- $\alpha$ and IL-6 inflammatory cytokines and their protein expressions in I/R rats. Marked inhibition of the apoptotic DNA and improvement of the architectures of small intestine were observed after pretreatment with ME. ME exhibits a protective effect against intestinal $\mathrm{I} / \mathrm{R}$ via amelioration of the oxidative stress and inflammatory cytokines gene expression. Therefore, the supplementation of ME prior to intestinal I/R might be helpful in the attenuation of $\mathrm{I} / \mathrm{R}$ complications.
\end{abstract}

Keywords: Methyl eugenol; ischemia reperfusion injury; intestine; TNF- $\alpha$; oxidative stress 


\section{Introduction}

Disruption of blood supply to an organ rapidly induces tissue damage. Although renewal of blood flow can relieve affected tissues after sustained ischemia, the reperfusion itself leads to additional injury called Ischemia-Reperfusion Injury (I/R) (Mallick et al. 2004). I/R is accompanied by a reduction in contractile activity, increased vascular permeability and damage in the mucosal barrier (Parks et al. 1988). Destroying the barrier integrity , besides being harmful for absorption of nutrient by mucosa, may cause bacterial translocation through the gut wall into the blood that causes an inflammatory response, systemic sepsis and organ dysfunction (Berg 1995). Many medical and surgical situations occur as a result of (I/R) of the intestine such as peripheral vascular insufficiency ,traumatic shock, myocardial infarction, mesenteric ischemia, as well as organ transplantation especially small bowel transplantation (SBT) (Collard and Gelman 2001; Dorweiler et al. 2007).

I/R may be contributed to many factors including reactive oxygen species (ROS) and cytokine release (Thurman 2007; Zingarelli et al. 2007). Free radicals can harm cellular membrane and subcellular structures that have great amounts of phospholipids, triggering lipid peroxidation and sequentially structural and metabolic changes that may cause cell apoptosis and necrosis (Thurman 2007).

Cytokines such as pro-inflammatory tumor necrosis factor alpha (TNF- $\alpha$ ) and antiinflammatory interleukine-6 (IL-6) play a vital role in preserving the homeostasis of the animal. They can start cascades of inflammation. Higher levels of cytokines can lead to several complications (Yao et al. 1997). Grotz et al. reported that TNF- $\alpha$ levels related to the severity of the intestinal ischemia and was found to be higher after 30 minutes of the reperfusion (Grotz et 
al. 1999). Several pro-inflammatory cytokines including TNF- $\alpha$ can induce apoptosis in the isolated epithelial cells, and their levels are increased in the mucosa and submucosa during I/R (Eliopoulos et al. 1996). Furthermore, TNF- $\alpha$ acts as trigger to the extrinsic pathway of apoptosis (Fulda and Debatin 2006; An et al. 2007), and hence affect caspase-3 expression (Mondello et al. 2010). Methyl eugenol (4-allyl-1,2-dimethoxybenzene) is a structurally analogue to eugenol. It is found naturally in many essential oils of the leaf and flora of several plants species. ME exhibits many biological effects such as relaxation and antispasmic actions on ileum smooth muscle in guinea-Pig (Lima et al. 2000). It causes reduction in the spontaneous motor activity in mammals' central nervous system, acts as anticonvulsant and has general anesthetic effects (Sell and Carlini 1976). Moreover, many vital pharmacological effects, including anti-inflammatory (Al-Sharif et al. 2013), analgesic, anesthetic, anticonvulsant, antibacterial, antihyperglycemic, antifungal and antiviral effects besides DNA protective properties have been reported (Yogalakshmi et al. 2010). In addition, eugenol and structurally related compounds have been reported as a potent antioxidant which could form complex compounds with reduced metals and inhibiting iron-mediated lipid peroxidation and autooxidation of $\mathrm{Fe}^{+}$ion (Choi et al. 2010; d'Avila Farias et al. 2014). Recently, ME has been prooven to induce a marked effect in the brain ischemia as it has been significantly attenuated superoxide generation and reduced the intracellular oxidative stress induced by oxygen glucose deprivation (OGD)/re-oxygenation (Choi et al. 2010).

Several strategies for the protection of intestine from I/R injury have been developed in the animal models, and some of these might find their way into clinical practice. To our knowledge, no information has been reported regarding methyl eugenol effect on I/R injury. 
Therefore, the present study was designed to investigate whether the administration of methyl eugenol exertes a protective effect against intestinal I/R injury based on a rat model of I/R injury.

\section{MATERIALS AND METHODS}

\section{Materials}

Methyl Eugenol was purchased from Sigma-Aldrich (St. Louis, USA). Kits for all biochemical parameters were purchased from Biodiagnostic Company (Giza, Egypt). All other chemicals were of high analytical grade and were purchased from Sigma-Aldrich (St. Louis, USA). Other molecular kits are listed elsewhere.

\section{Animals}

Adult male Wistar rats (Rattus norvegicus) weighing $(250-300 \pm 5 \mathrm{~g})$ were used in this study. The experimental protocol was approved by Institutional Animal Care and Use Committee (IACUC), Faculty of Science, Cairo University (Egypt) (CUFS/F/PHY/37/15). All the experimental procedures were carried out in accordance with international guidelines for care and use of laboratory animals. All animals were acclimatized to laboratory conditions for one week before the beginning of the experiment. Animals had unrestricted access to standard laboratory diet and water ad libitum. They were housed 7 per cage and kept under standard conditions at a room temperature of $22-24^{\circ} \mathrm{C}$ with a $12 \mathrm{~h}$ light $/ 12 \mathrm{~h}$ dark cycle and were fasted for $12 \mathrm{~h}$ with water ad libitum before starting the operation.

\section{Experimental Design}

Animals were divided into four main groups (7/group) as follow:

Methyl eugenol group (ME); received ME (100 mg/kg) (Sanchez-Mendoza et al. 2015) by oral intubation for 30 days. Sham-operated group (Sham); received saline orally for 30 days and underwent laparotomy without clamping. Intestinal Ischemia group (I/R); received saline orally 
for 30 days and underwent laparotomy occlusion of superior mesentric artery (SMA) for $30 \mathrm{~min}$ of ischemia followed by $60 \mathrm{~min}$ of reperfusion (Guneli et al. 2007), Intestinal IschemiaReperfusion group plus ME (ME $+\mathrm{I} / \mathrm{R})$; received ME $(100 \mathrm{mg} / \mathrm{kg})$ by oral intubation for 30 days and underwent laparotomy with SMA occlusion $30 \mathrm{~min}$ of ischemia followed by 60 min of reperfusion.

\section{Operative procedures}

Laparotomy was performed by occlusion of the (SMA) with a microvascular clamp. Briefly, rats were anesthetized by intramuscular injection of $(50 \mathrm{mg} / \mathrm{kg}) \mathrm{ketamine}$, combined with (10 $\mathrm{mg} / \mathrm{kg}$ ) xylazine. During surgery, the rats were allowed to have spontaneous breathing. Animals were resuscitate with $1 \mathrm{ml}$ subcutaneous $0.9 \%$ saline and their body temperature was kept at $37^{\circ} \mathrm{C}$ by a heating pad. Under aseptic conditions, the abdomen was carefully cleaned with $10 \%$ iodine and opened by a midline incision with bilateral subcostal extensions. The SMA was visualized and clamped using atraumatic microvascular clamp and ischemia was maintained for 30 minutes. During the ischemic time, the mesenteric ischemia was evaluated by loss of mesenteric pulsation and the pale appearance. Following the ischemia, the reperfusion was initiated by removing the occluding clamp and was confirmed by the return of pulsation of the pedicle and the reperfusion period was maintained for 60 minutes. The animal's anesthesia was assessed during the whole experimental period. To reduce the pain during the time that animals were still awakened for ischemia and reperfusion procedures, rats were given an intraperitoneal injection of Buprenorphine $0.1 \mathrm{mg} / \mathrm{kg}$ (Ban et al. 2013). All animals were humanely sacrificed by exsanguination where they still under the effect of anesthesia. No mortality among rats occurred during the experiment. Small bowel samples were obtained after euthanasia and divided into three parts, first part was snap frozen in liquid nitrogen and preserved below $-80{ }^{\circ} \mathrm{C}$ for DNA fragmentation, second one was fixed in $10 \%$ formalin for histochemical and 
immunohistochemically examination, and finally the third part was preserved in $1 \mathrm{ml}$ RNA later and was kept at $-80^{\circ} \mathrm{C}$ for real-time analysis. Blood was collected at the end of the reperfusion period via cardiac puncture and centrifuged at 3000 r.p.m for 10 minutes. The obtained serum was stored at $-80^{\circ} \mathrm{C}$ for Elisa analysis.

\section{Biochemical Analysis:}

The entire small intestine was removed, the intestinal lumen was flushed with cold saline and the tissues were homogenized $(10 \% \mathrm{w} / \mathrm{v})$ in ice-cold $0.1 \mathrm{M}$ Tris-HCl buffer $(\mathrm{pH} 7.4)$. The homogenate was centrifuged at 3000 r.p.m. for $15 \mathrm{~min}$ at $4^{\circ} \mathrm{C}$ and the resultant supernatant was used for the biochemical analyses.

\section{Lactate Dehydrogenase}

To assess the index of intestinal tissue damage, Lactate Dehydrogenase (LDH) was measured in the serum samples of all animal groups. The levels of LDH were measured using the commercial kinetic ultraviolet kit (Salucea, Haansberg, Netherlands). The initial rate of Nicotinamide Adenine Dinucleotide (NADH) oxidation is directly proportional to the catalytic LDH activity and expressed by U/L (Van der Heiden et al. 1994).

\section{Oxidative Stress Assessment:}

\section{Malondialdehyde (MDA) Assay}

The tissue content of MDA (an index of oxidative stress mediated tissue lipid peroxidation), was determined by the thiobarbituric acid (TBA) method, as described previously (Ohkawa et al. 1979). The small intestinal mucosa was homogenized with ice-cold $0.1 \mathrm{M}$ Tris$\mathrm{HCl}$ buffer $(\mathrm{pH} \mathrm{7.4)}$ and the values of MDA in tissue homogenate were expressed as $\mathrm{nmol} / \mathrm{g}$ tissue.

Glutathione-S-transferase (GST) and Reduced glutathione (GSH) of the small intestinal tissue 
GST and GSH play a major role in protecting cells against damage from ROS. Tissue GST and GSH were assessed in the homogenate according to the manufacturer's instructions (Beutler et al. 1963; Habig et al. 1974).

\section{Superoxide Dismutase (SOD) Assay}

The method of measuring SOD activity depends on the inhibition of nitro blue tetrazolium (NitroBT) (NBT) reduction by xanthine- -xanthine oxidase after addition of superoxide dismutase (Nishikimi et al. 1972). SOD activity was designated as unit/gm of intestinal tissue.

\section{Catalase (CAT) Assay}

The catalase activity in the intestinal tissue was determined by the method described by Aebi (1984), in which the supernatant was incubated with $\mathrm{H}_{2} \mathrm{O}_{2}$ and the reaction was stopped with catalase inhibitor. The color intensity of the complex formed by chromophore and $\mathrm{H}_{2} \mathrm{O}_{2}$ was inversely proportional to the amount of catalase in the sample and measured at $510 \mathrm{~nm}$ (Aebi 1984).

\section{Nitric Oxide (NO) Assay}

Nitric Oxide was estimated colorimetrically with the Griess reagent (Montgomery and Dymock 1961). Tissue nitric oxide was measured at $540 \mathrm{~nm}$ and expressed as umol/L.

\section{Enzyme-linked immunosorbent assay (ELISA)}

Immunoreactivity TNF- $\alpha$ was measured with Elisa kit purchased from (Komabiotech, Korea) according to the manufacturer's instructions and as described previously (Funakoshi et al. 2012)

Quantitative Real Time (qRT-PCR) 
Synthesized cDNA was quantified using SYBR green-based real-time PCR and was detected with 7500 Fast systems (Applied Biosystem 7500, USA). Total volume for each PCR reaction was $25 \mathrm{~mL}$ according to the manufacturer's protocol. The thermal cycling condition comprised an initial heat activation step at $95^{\circ} \mathrm{C}$ for $15 \mathrm{~min}$ followed by 40 cycles of denaturation at $95^{\circ} \mathrm{C}$ for $15 \mathrm{~s}$, with annealing temperatures $53^{\circ} \mathrm{C}$ for $T N F-\alpha, 50^{\circ} \mathrm{C}$ for $I L 6$ and $57^{\circ} \mathrm{C}$ for $G A P D H$ and elongation at $60^{\circ} \mathrm{C}$ for $1 \mathrm{~min}$. The primer sequences are listed in table 1 . Each sample was prepared in triplicate for each gene. The results of these genes were normalized to $G A P D H$. Dissociation curves were also conducted after amplification to ensure the reaction specificity. The amplification curve begins after the maximum baseline and the threshold was set in the exponential phase of the amplification curve. Relative quantification of gene expression was performed using the comparative $\mathrm{Ct}$ method $(\Delta \Delta \mathrm{Ct})$ by comparing a number of cDNA copies in different samples among each other. $\Delta \Delta \mathrm{Ct}=\Delta \mathrm{Ct}$ target $-\Delta \mathrm{Ct}$ GAPDH. The relative quantification of mRNA was calculated for statistical analysis $R Q=2^{-\Delta \Delta C t}$. The results were demonstrated in a graph as mean \pm Standard Error (SE) values of relative change compared to the sham group using Prism (Graph Pad Software, San Diego, California, USA, version 5.01).

\section{Table 1.}

\section{TNF- $\alpha$ and caspase-3 Immunohistochemistry}

Immunohistochemistry (IHC) was performed to detect the location and the distribution of TNF- $\alpha$ and caspase- 3 positive cells using a streptavidin-biotin method by (Santa Cruz Biotechnology kit, USA). Sections were deparaffinized in xylene and rehydrated in decreasing concentrations of alcohol followed by washing with water. Background staining was blocked with powdered skim milk (3\% in phosphate buffered saline). Endogenous peroxidase was blocked by hydrogen peroxide $3 \%$ then it was blocked with normal goat serum at $37^{\circ} \mathrm{C}$ for 15 
min. Slides were incubated with polyclonal antibodies of TNF- $\alpha$ or caspase-3 (diluted to $1: 100$, Santa Cruz Biotechnology) at $37^{\circ} \mathrm{C}$ for $60 \mathrm{~min}$. After washing with PBS, the slides were incubated with a biotinylated horse peroxidase-conjugated secondary antibody and $0.1 \%$ DAB substrate, using the standard streptavidin-biotin-based method. Incubation with PBS instead of the primary antibody served as a negative control. The brown granule was marked as a positive expression for either TNF- $\alpha$ or caspase-3Visual scoring was performed by counting the numbers of positive cells in five villi of the small intestine in three sections/animal for each tested protein. Sections were examined with an optical image analyzer (Olympus CX41, Japan). The sections were photographed with a digital Olympus camera (SC100, Japan) connected to the computer with high power (400-fold magnification).

\section{Histopathological Analysis}

Morphological changes in the intestine were examined by hematoxylin and eosin (H\&E) staining. Small intestinal tissues were fixed in $10 \%$ buffered neutral formalin, embedded in paraffin and then cut into $4-\mu \mathrm{m}$ sections to be evaluated microscopically. Intestinal mucosa damage was evaluated according to Chiu's histological injury scoring system of intestinal villi (Chiu et al. 1970). Chiu score consists of 0-5 grades that are described as follow: Grade 0: Mucosa with normal villi. Grade 1: Developing of the subepithelial spaces (Gruenhagen's space), usually at the villus apex, frequently associated with capillary congestion. Grade 2: Extension of subepithelial space with the moderate lifting of epithelial layer from the lamina propria. Grade 3 : Massive epithelial lifting down the sides of the villi. Grade 4: Denuded villi with lamina probria and dilated capillaries exposed. Increased cellularity of lamina propria may be noted. Grade 5: Digestion and disintegration of lamina propria; hemorrhage and ulceration. Digital images were acquired at random in a blinded manner using (Olympus CX41, Japan) image microscope 
analyzer provided with digital Olympus camera (SC100, Japan). Five digital images per animal were studied using a semi-quantitative score that evaluates the histological criteria.

\section{DNA-Ladder fragmentation}

We followed the DNA extraction method of Sambrook et al (Sambrook and Russell David 1989), the intestinal tissues were homogenized in sarkowsyl (10 mM Tris-HCl/20mM EDTA/0.5\% N-lauroylsarcosine, $\mathrm{pH} 7.8$ ) buffer for $20 \mathrm{~min}$ on ice before centrifugation and incubated with proteinase- $\mathrm{K}$ at $50^{\circ} \mathrm{C}(50 \mathrm{mg} / \mathrm{ml})$ for $2 \mathrm{~h}$. By then, DNA was extracted with phenol-chloroform three times and then precipitated with absolute ethanol and $2.5 \mathrm{M}$ sodium acetate $(\mathrm{pH} 4.0)$. DNA was washed three times with $66 \%$ ethanol and dissolved in $0.1 \mathrm{M}$ Tris$\mathrm{HCl} / 20 \mathrm{mM}$ EDTA buffer ( $\mathrm{pH} 8.0$ ), then digested for $15 \mathrm{~min}$ at $37^{\circ} \mathrm{C}$ with DNAse-free RNAseA $(1 \mathrm{mg} / \mathrm{ml})$. Later, DNA was re-extracted in chloroform and reprecipitated with absolute ethanol and 2.5 M sodium acetate ( $\mathrm{pH} 4.0)$. A specific quantity (15 mg/lane) was loaded onto $1.2 \%$ agarose gel containing $0.4 \mathrm{mg} / \mathrm{ml}$ ethidium. Electrophoresis was carried out in a large submarine at $60 \mathrm{~V}$. The gel was examined and photographed under UV light using Medidoc gel documentation system (Herolab, Wiesloch, Germany) to visualize DNA fragmentation (laddering), characteristic of apoptosis.

\section{Statistical analysis}

Data were analyzed using statistical software (SPSS for windows 19.0, SPSS Inc, Chicago, USA). All the results were expressed as means \pm SEM for each group. The differences among experimental groups were detected by one-way analysis of variance (ANOVA). A $P$ value of less than 0.01 was considered to be statistically significant. 


\section{Results}

\section{Intestinal Oxidative Stress}

Intestinal $\mathrm{I} / \mathrm{R}$ significantly increased the serum LDH $(P<0.01)$, tissue MDA and NO levels $(P<0.01)$ and reduced the endogenous antioxidant biomarkers GSH, GST, SOD and CAT activities $(P<0.01)$ when compared to sham group. ME significantly $(P<0.01)$ decreased the elevated LDH, MDA, and NO levels and concurrently increased the antioxidant biomarkers under test in the intestinal tissue (Table 2).

Table 2.

\section{Serum TNF- $\alpha$ concentration}

As shown in (Figure 1) TNF- $\alpha$ level in serum increased significantly $(P<0.01)$ in $\mathrm{I} / \mathrm{R}$ group, and decreased significantly $(P<0.01)$ after ME treatment when compared to sham and I/R group.

Fig. 1.

mRNA Expression of TNF- $\alpha$ and IL-6 
The expression of $T N F-\boldsymbol{\alpha}$ and $I L-6$ genes at the level of mRNA were studied by real-time PCR (Fig. 2). The results showed that the expression levels of mRNA for both $T N F-\alpha$ and $I L-6$ were significantly higher $(T N F-\alpha, 2.5$ fold $P<0.01$ and $I L-6,10$ fold $P<0.01)$ in rats subjected to $\mathrm{I} / \mathrm{R}$. Treatment with ME prior to I/R injury significantly down-regulated the levels of $T N F-\alpha$ and $I L-6(P<0.01)$ when compared to I/R (Fig. 2).

\section{Fig. 2.}

\section{TNF- $\alpha$ and caspase 3 Immunohistochemistry}

$T N F-\alpha$ and caspase-3 protein expressions were detected immunohistochemically by counting positive cells in small intestine after $30 \mathrm{~min}$ ischemia and $60 \mathrm{~min}$ reperfusion for each in four regions/image/ protein using high power magnifications. Positive cells of TNF- $\alpha$ and caspase-3 were found to be highly expressed in I/R groups (Fig.3C) when compared with sham and ME groups (3A, 3B) and were downregulated in $\mathrm{ME}+\mathrm{I} / \mathrm{R}$ group (Fig.3D). Figures (3E) and (4E) represent the numbers of TNF- $\alpha$ and caspase-3 positive cells respectively, in small intestinal tissues in the Sham, ME, I /R, and ME $+\mathrm{I} / \mathrm{R}$ groups. Both TNF- $\alpha$ and caspase-3 cells were significantly increased $(P<0.01)$ in $\mathrm{I} / \mathrm{R}$ group compared with Sham and ME groups $(P<0.01)$, and decreased significantly $(P<0.01)$ after ME treatment when compared to Sham and I/R group.

\section{Fig. 3 and Fig.4}

\section{Histopathological Analysis}

Microscopic examination of the intestinal tissue stained with H\&E showed no histopathological alteration in mucosal injury in the sham-operated and ME groups (Fig.5A, 5B). 
While, shortening, thickening of the villi, necrosis of the intestinal villi, inflammatory cells infiltration and hemorrhage in lamina propria were observed in I/R treated group (Fig.5C). These changes were ameliorated by pretreatment with ME before ischemia and reperfusion (Fig.5D). By using the Chiu scoring system, we evaluated the severity of mucosal injury to the intestines after $\mathrm{I} / \mathrm{R}$ via a numerical grading score from 0 to 5 . The score of damage of the small intestinal tissues was significantly pronounced in I/R group $(4.13 \pm 0.55)$ when compared with the sham $(1.21 \pm 0.44), \mathrm{ME}(1.40 \pm 0.24)$ and $\mathrm{ME}+\mathrm{I} / \mathrm{R}(1.80 \pm 0.20)$ operated group $(P<0.01)($ Fig.5E)

\section{Fig.5}

\section{DNA-Ladder fragmentation}

DNA fragmentation is a marker of late-stage apoptosis (Fig 6). As shown in figure 5, sham groups did not induce any DNA fragmentation (lane 2). On contrary, DNA fragmentation of $\mathrm{I} / \mathrm{R}$ group was evidenced by the appearance of fragmentized DNA in the form of both laddered (at 250, $200 \mathrm{bp}$ ) and smeared DNA fragments (lane 4). DNA damage was markedly reduced by administration of methyl eugenol in $\mathrm{ME}+\mathrm{I} / \mathrm{R}$ group as indicated by disappearance of laddered DNA and existence of slight smear DNA fragments induced by I/R (Lanes 5).

\section{Fig.6}

\section{Discussion}

Many reports have demonstrated that methyl eugenol plays an important role in preventing oxidative stress. However, methyl eugenol role in the prevention of intestinal $I / R$ is unknown. Thus, our study is the first to demonstrate that methyl eugenol (ME) conveys a protective effect, possibly through an attenuation of oxidative stress locally and systemically. This has important potential clinical implications, because unlike other chemical agents, ME can 
be given intraoperatively without the risk of residual postoperative adverse effects such as respiratory depression and gut dysmotility (Asha et al. 2001). Previous study indicated that methyl eugenol induced several carcinogenic activity in different organs of F344 rats and B6C3F1 mice at dose range 150-300 mg/kg/day indicating its toxicity (Johnson et al. 2000). Nevertheless, the dose used in our study $(100 \mathrm{mg} / \mathrm{kg} /$ day for 30 days $)$ is so far from the LD50 of methyl eugenol (850-1560 mg/kg) which was measured previously (Abdo et al. 2001), In addition, ME at many subchronic doses for 14 weeks long indicated several toxic effects such as hepatocellular damage in rat, Cholestasis, altered hepatic functions, hypoproteinemia, an hypoalbuminemia, atrophic gastritis and adrenal gland cortical hypertrophy (Abdo et al. 2001). Despite of all these toxic effects, it has been proven to induce multi-functional cytoprotective activities including anti-oxidative and anti-inflammatory activities at dose $100 \mathrm{mg} / \mathrm{kg}$ b.w.(Choi et al. 2010).

The production of free radicals and oxidants are dramatically increased during ischemia and reperfusion (Robin et al. 2007; Liu et al. 2015). Cellular ATP is catabolized to yield hypoxanthine and also activates the conversion of xanthine dehydrogenase (XDH) to the oxygen radical producing xanthine oxidase $(\mathrm{XO})$. During reperfusion, molecular oxygen is introduced again into the tissue and reacts with hypoxanthine and $\mathrm{XO}$ to produce oxygen free radicals, superoxide anion $\left(\mathrm{O}_{2}^{-}\right)$and hydrogen peroxide radical $\left(\mathrm{OH}^{\circ}\right) \cdot \mathrm{O}_{2}$ and $\mathrm{H}_{2} \mathrm{O}_{2}$ react with iron and produce $\mathrm{OH}^{\bullet}$ radicals. Reactive Oxygen species (ROS) destroy polyunsaturated lipids, forming malondialdehyde (MDA, an indicator for intestinal oxidative stress (Gutteridge 1995). In addition, Lactate dehydrogenase (LDH), that is found in the cytoplasm of all major organs, catalysis the oxidation of L-lactate to pyruvate, which is the final step in the metabolic chain of 
anaerobic glycolysis, and thus, used as a marker for tissue damage index. During ischemic period, LDH is released into the peripheral blood after cell death (Lott and Nemensanszky 1987).

Glutathione is an important intracellular antioxidant that dramatically decrease in the intestinal tissue after intestinal I/R (Stefanutti et al. 2008). Glutathione scavenges $\mathrm{O}_{2}^{-\bullet}$ and protects protein thiol groups from oxidation. Intestinal epithelial cells contain members of the GST family that catalyze the conjugation of GSH with endogenous compounds such as lipids peroxidase and promote the detoxification process. GST may also bind toxins and function as transport proteins (Leaver and George 1998). It is well known that the GST-GSH is an important antioxidant system. The drop in GSH levels during IR was probably due to its consumption during oxidative stress (Stefanutti et al. 2008). Moreover, SOD specially detoxifies $\mathrm{O}_{2}{ }^{--}$to $\mathrm{H}_{2} \mathrm{O}_{2}$, which by then scavenged by CAT during I/R (Zeng et al. 2016). Increased levels of oxidative stress were observed in I/R injury, accompanied by reduced scavenging ability against oxidative injuries such as the low activity of SOD (Xiao et al. 1997; Vincenti et al. 2010). Consistent with previous studies, increased MDA, LDH production and reduced activity of SOD were observed in the rat model of intestinal I/R (Ozkan et al. 2009). Reduced MDA and increased SOD levels were found in rats with $\mathrm{I} / \mathrm{R}$ that received pre-treatment with $\mathrm{ME}$, indicating that the administration of $\mathrm{ME}$, the potent antioxidant, could attenuate oxidative injury may be by its ability to form complexes with reduced metals and inhibiting iron-mediated lipid peroxidation and auto-oxidation of $\mathrm{Fe}^{+}$ion (d'Avila Farias et al. 2014). Overproduction of ROS and NO may directly injure the mucosa during I/R. NO is a free radical and a highly reactive substance. The initiation of inducible nitric oxide (iNOS) due to intestinal I/R, produces large amounts of NO, while endothelial nitric oxide synthase (eNOS), that has a protective effect at the onset of injury, was deactivated during oxidative stress (Münzel et al. 2005). Superoxide anion radicals may 
react with NO turning it into cytotoxic peroxynitrite leading to tissue injury, and therefore, specific inhibition of this enzyme is mandatory for tissue protection (Kubes and McCafferty 2000).

Consequently, I/R induces mitochondrial respiratory dysfunction (Keshav et al. 1990; Zheng et al. 2009) through overproduction of NO which can trigger apoptosis via an increase in mitochondrial permeability, that results in the liberation of apoptogenic factors from mitochondria (Henninger et al. 1995), or may be due to the release of cytochrome c from mitochondria to cytosols (Pacher and Hajnóczky 2001), so the elevation of NO level was a reason for the progress of apoptosis. As the cleaved caspase- 3 expression is strongly related to the apoptosis (Aban et al. 2005), it has been demonstrated that the elevation of TNF- $\alpha$ level increases the expression of the proapoptotic protein cleaved caspase- 3 and thus induces apoptosis induction (Aban et al. 2005; Mondello et al. 2010), as indicated by the increased expression of caspase-3 protein and apoptotic laddering in the intestinal tissues of animals subjected to I/R and less apoptotic deflagration in $\mathrm{I} / \mathrm{R}+\mathrm{ME}$ group.

Additionally, Hydroxyl radicals stimulate free chain reaction then cause lipid peroxidation and DNA fragmentation (Harrison 2002). Interestingly, our results demonstrated the marked elevation of NO level and DNA fragmentation after $30 \mathrm{~min}$ of ischemia and one hour of reperfusion. While these levels were reduced after the administration of ME which acts as strong scavengers of oxygen free radicals and reduces the levels of ROS and NO (Atsumi et al. 2005; Choi et al. 2010; de Sá Júnior et al. 2016).

IL-6 and TNF- $\alpha$ are vital pro-inflammatory cytokines and are regarded as molecular markers of inflammatory responses in human cells (Molmenti et al. 1993). The small intestine was recognized as the principal source of the pro-inflammatory cytokines, where large amounts 
of resident macrophages exist in the lamina propria of the intestinal mucosa and some other cells, such as enterocytes and Paneth cells (Keshav et al. 1990; Zheng et al. 2009). I/R recruits and triggers neutrophils in the intestine and consequently causes a significant elevation of TNF- $\alpha$ and IL-6 in serum(Gregová et al. 2013). The rising of these pro-inflammatory cytokines (TNF- $\alpha$ and IL-6) causes leukocyte infiltration to the damaged tissue (Nezu et al. 2008). Our findings revealed significant overexpressions of IL6 and TNF- $\alpha$ genes with an elevation in TNF- $\alpha$ protein expression in the intestinal tissues and elevation of TNF- $\alpha$ level in the serum after I/R when compared to those pretreated with ME. These results are in agreement with many recent reports that detected such elevations of IL6 and TNF- $\alpha$ levels in serum after intestinal I/R in rat (Liu et al. 2015; Lin et al. 2014). These findings prove the hypothesis of that releasing of IL-6 occurs following intestinal $\mathrm{I} / \mathrm{R}$, was mediated via TNF-dependent mechanisms providing a complex interaction between both (Yao et al. 1997). The current data showed that ME markedly reduced TNF- $\alpha$ serum concentration and its gene and protein expression as well as mRNA gene expression of $I L-6$ after Intestinal I/R. This is contributed to the inhibition of macrophages by ME as revealed by De Paula Porto, et al., (de Paula Porto et al. 2014).

The anti-inflammatory activity of ME may be attributed not only to its antioxidant activities but also to its interaction with signaling cascades involving cytokines and regulatory transcription factors, and its effect on the expression of pro-inflammatory genes (Miguel 2010). It was mentioned that $\mathrm{I} / \mathrm{R}$ is the key stimulus in the regulation of NF- $k \mathrm{~B}$. By maintaining the interaction between $\mathrm{IkB} \alpha$ and $\mathrm{NF}-\mathrm{kB}$ (Spiecker et al. 1998). The anti-inflammatory effect of ME may attribute to downregulation of $\mathrm{I} \kappa \mathrm{B} \alpha$ phosphorylation, a critical step in NF- $\kappa \mathrm{B}$ activation, and thus, blocking the NF- $\kappa \mathrm{B}$ signaling cascade (Yamamoto et al. 2001; Manikandan et al. 2010).Consequently, ME effectively improved the functional and structural intestinal mucosa 
alterations induced by I/R, by inhibition of NF- $\kappa$ B activation and TNF- $\alpha$ release (Bachiega et al. 2012). So our results demonstrated that ME may regulate the pro-inflammatory (TNF- $\alpha$, IL-6) cytokines after intestinal $\mathrm{I} / \mathrm{R}$.

Particularly, villi and intestinal mucosa are one of the most sensitive tissues to $\mathrm{I} / \mathrm{R}$ (Yamamoto et al. 2001; Vincenti et al. 2010). Severe damage in the architecture of the small intestine was observed after $30 \mathrm{~min}$ ischemia and one-hour reperfusion. Structural investigations have revealed that epithelial cells of mucosal villi were completely denuded accompanied with an infarction of the submucosa and muscularis layers, as well as an increase in Chiu's scores in the intestinal mucosa (Chiu et al. 1970). Chiu has shown that ischemia of the small intestine causes necrosis which begins at the tips of the villi and gradually progresses towards the serosal surface. Our findings demonstrated methyl eugenol pretreatment attenuated villi damage in the rat model of $\mathrm{I} / \mathrm{R}$, indicating the therapeutic application of $\mathrm{ME}$ in intestinal $\mathrm{I} / \mathrm{R}$. In conclusion, as the main pathophysiological reperfusion injury of rat's intestine is the significant mucosal alteration. Our study has demonstrated that systemic administration of ME given before tissue ischemia allowing us to bypass the inherent adverse effects of $\mathrm{I} / \mathrm{R}$ and promotes earlier and complete structural regeneration in rats with critical partial intestinal ischemia. Based on these findings, ME is worthy of further mechanistic and clinical investigation as a potential novel naturally intervention strategy in ischemia-reperfusion of the intestine and other organs.

Conflict of interest: There is no conflict of interest

\section{Acknowledgement}

Author would like to thank Prof. Dr. Koukap Abd-Elazez Ahmed for her great help in sectioning, staining, photographing and examining the histological specimens.

\section{References}


Aban, N.; Cinel, L.; Tamer, L.; Aktas, A. and Aban, M. 2005. Ischemic preconditioning reduces caspase-related intestinal apoptosis'. Surg. Today, 35, 228-34.

Abdo, K. M.; Cunningham, M. L.; Snell, M. L.; Herbert, R. A.; Travlos, G. S.; Eldridge, S. R., et al. 2001. 14-Week toxicity and cell proliferation of methyleugenol administered by gavage to F344 rats and B6C3F1 mice'. Food Chem. Toxicol., 39, 303-16.

Aebi, H. 1984. [13] Catalase in vitro'. Methods Enzymol., 105, 121-26.

Al-Sharif, I.; Remmal, A. and Aboussekhra, A. 2013. Eugenol triggers apoptosis in breast cancer cells through E2F1/survivin down-regulation'. BMC Cancer, 13, 600.

An, S.; Hishikawa, Y.; Liu, J. and Koji, T. 2007. Lung injury after ischemia-reperfusion of small intestine in rats involves apoptosis of type II alveolar epithelial cells mediated by TNFalpha and activation of Bid pathway'. Apoptosis, 12, 1989-2001.

Asha, M. K.; Prashanth, D.; Murali, B.; Padmaja, R. and Amit, A. 2001. Anthelmintic activity of essential oil of Ocimum sanctum and eugenol'. Fitoterapia, 72, 669-70.

Atsumi, T.; Fujisawa, S. and Tonosaki, K. 2005. A comparative study of the antioxidant/prooxidant activities of eugenol and isoeugenol with various concentrations and oxidation conditions'. Toxicol. In Vitro, 19, 1025-33.

Bachiega, T. F.; de Sousa, J. P. B.; Bastos, J. K. and Sforcin, J. M. 2012. Clove and eugenol in noncytotoxic concentrations exert immunomodulatory/anti-inflammatory action on cytokine production by murine macrophages'. J. Pharm. Pharmacol., 64, 610-16.

Ban, K.; Peng, Z. and Kozar, R. A. 2013. Inhibition of ERK1/2 worsens intestinal ischemia/reperfusion injury'. PLoS One, 8, e76790.

Berg, R. D. 1995. Bacterial translocation from the gastrointestinal tract'. Trends Microbiol., 3, 149-54.

Beutler, E.; Duron, O. and Kelly, B. M. 1963. Improved method for the determination of blood glutathione'. J Lab Clin Med., 61, 882-88.

Chiu, C. J.; McArdle, A. H.; Brown, R.; Scott, H. J. and Gurd, F. N. 1970. Intestinal mucosal lesion in low-flow states. I. A morphological, hemodynamic, and metabolic reappraisal'. Arch. Surg., 101, 478-83.

Choi, Y. K.; Cho, G. S.; Hwang, S.; Kim, B. W.; Lim, J. H.; Lee, J. C., et al. 2010. Methyleugenol reduces cerebral ischemic injury by suppression of oxidative injury and inflammation'. Free Radic. Res., 44, 925-35. 
Collard, C. D. and Gelman, S. 2001. Pathophysiology, clinical manifestations, and prevention of ischemia-reperfusion injury'. Anesthesiology, 94, 1133-8.

d'Avila Farias, M.; Oliveira, P. S.; Dutra, F. S. P.; Fernandes, T. J.; Pereira, C. M.; Oliveira, S. Q., et al. 2014. Eugenol derivatives as potential anti-oxidants: is phenolic hydroxyl necessary to obtain an effect?'. J. Pharm. Pharmacol., 66, 733-46.

de Paula Porto, M.; Da Silva, G. N.; Luperini, B. C. O.; Bachiega, T. F.; de Castro Marcondes, J. P.; Sforcin, J. M., et al. 2014. Citral and eugenol modulate DNA damage and proinflammatory mediator genes in murine peritoneal macrophages'. Mol. Biol. Rep., 41, 7043-51.

de Sá Júnior, P. L.; Câmara, D. A. D.; Costa, A. S.; Ruiz, J. L. M.; Levy, D.; Azevedo, R. A., et al. 2016. Apoptotic effect of eugenol envolves G2/M phase abrogation accompanied by mitochondrial damage and clastogenic effect on cancer cell in vitro'. Phytomedicine, 23, 725-35.

Dorweiler, B.; Pruefer, D.; Andrasi, T. B.; Maksan, S. M.; Schmiedt, W.; Neufang, A., et al. 2007. Ischemia-Reperfusion Injury : Pathophysiology and Clinical Implications'. Eur. J. Trauma Emerg. Surg., 33, 600-12.

Eliopoulos, A. G.; Dawson, C. W.; Mosialos, G.; Floettmann, J. E.; Rowe, M.; Armitage, R. J., et al. 1996. CD40-induced growth inhibition in epithelial cells is mimicked by EpsteinBarr Virus-encoded LMP1: involvement of TRAF3 as a common mediator'. Oncogene, 13, 2243-54.

Fulda, S. and Debatin, K. M. 2006. Extrinsic versus intrinsic apoptosis pathways in anticancer chemotherapy'. Oncogene, 25, 4798-811.

Funakoshi, T.; Yamashita, K.; Ichikawa, N.; Fukai, M.; Suzuki, T.; Goto, R., et al. 2012. A novel $\mathrm{NF}-\kappa \mathrm{B}$ inhibitor, dehydroxymethylepoxyquinomicin, ameliorates inflammatory colonic injury in mice'. Journal of Crohn's and Colitis, 6, 215-25.

Gregová, K.; Čikoš, S.; Czikková, S.; Bilecová-Rabajdová, M.; Urban, P. and Veselá, J. 2013. Effects of intestinal ischemia reperfusion injury on the level of specific genes in rats'. Journal of Ecology and Health, 17.

Grotz, M.; Deitch, E. A.; Ding, J.; Xu, D.; Huang, Q. and Regel, G. 1999. Intestinal cytokine response after gut ischemia: role of gut barrier failure'. Ann. Surg., 229, 478. 
Guneli, E.; Cavdar, Z.; Islekel, H.; Sarioglu, S.; Erbayraktar, S.; Kiray, M., et al. 2007. Erythropoletin Protects the Intestine Against Ischemia/Reperfusion Injury in Rats'. Molecular medicine-cambridge ma then new york-, 13, 509.

Gutteridge, J. 1995. Lipid peroxidation and antioxidants as biomarkers of tissue damage'. Clin. Chem., 41, 1819-28.

Habig, W. H.; Pabst, M. J. and Jakoby, W. B. 1974. Glutathione S-transferases. The first enzymatic step in mercapturic acid formation'. J. Biol. Chem., 249, 7130-9.

Harrison, R. 2002. Structure and function of xanthine oxidoreductase: where are we now?'. Free Radical Biology and Medicine, 33, 774-97.

Henninger, D. D.; Granger, D. N. and Aw, T. 1995. Enterocyte respiration rates in feline small intestine exposed to graded ischemia'. Am. J. Physiol. Gastrointest. Liver Physiol., 268, G116-G20.

Johnson, J. D.; Ryan, M. J.; Toft, J. D.; Graves, S. W.; Hejtmancik, M. R.; Cunningham, M. L., et al. 2000. Two-year toxicity and carcinogenicity study of methyleugenol in F344/N rats and B6C3F1 mice'. J. Agric. Food Chem., 48, 3620-32.

Keshav, S.; Lawson, L.; Chung, L.; Stein, M.; Perry, V. and Gordon, S. 1990. Tumor necrosis factor mRNA localized to Paneth cells of normal murine intestinal epithelium by in situ hybridization'. J. Exp. Med., 171, 327-32.

Kubes, P. and McCafferty, D.-M. 2000. Nitric oxide and intestinal inflammation'. Am. J. Med., 109, 150-58.

Leaver, M. and George, S. 1998. A piscine glutathione S-transferase which efficiently conjugates the end-products of lipid peroxidation'. Mar. Environ. Res., 46, 71-74.

Lima, C. C.; Criddle, D. N.; Coelho-de-Souza, A. N.; Monte, F. J.; Jaffar, M. and Leal-Cardoso, J. H. 2000. Relaxant and antispasmodic actions of methyleugenol on guinea-pig isolated ileum'. Planta Med., 66, 408-11.

Lin, Z.-L.; Yu, W.-K.; Tan, S.-J.; Duan, K.-P.; Dong, Y.; Bai, X.-W., et al. 2014. Protective effects of terminal ileostomy against bacterial translocation in a rat model of intestinal ischemia/reperfusion injury'. World J. Gastroenterol., 20, 17905.

Liu, X. H.; Yang, Y. W.; Dai, H. T.; Cai, S. W.; Chen, R. H. and Ye, Z. Q. 2015. Protective role of adiponectin in a rat model of intestinal ischemia reperfusion injury'. World J. Gastroenterol., 21, 13250-8. 
Lott, J. A. and Nemensanszky, E. 1987. Lactate dehydrogenase'. Clinical Enzymology, a Caseoriented Approach, 213-44.

Mallick, I. H.; Yang, W.; Winslet, M. C. and Seifalian, A. M. 2004. REVIEW: IschemiaReperfusion Injury of the Intestine and Protective Strategies Against Injury'. Dig. Dis. Sci., 49, 1359-77.

Manikandan, P.; Murugan, R. S.; Priyadarsini, R. V.; Vinothini, G. and Nagini, S. 2010. Eugenol induces apoptosis and inhibits invasion and angiogenesis in a rat model of gastric carcinogenesis induced by MNNG'. Life Sci., 86, 936-41.

Miguel, M. G. 2010. Antioxidant and anti-inflammatory activities of essential oils: a short review'. Molecules, 15, 9252-87.

Molmenti, E. P.; Ziambaras, T. and Perlmutter, D. H. 1993. Evidence for an acute phase response in human intestinal epithelial cells'. J. Biol. Chem., 268, 14116-24.

Mondello, S.; Galuppo, M.; Mazzon, E.; Domenico, I.; Mondello, P.; Carmela, A., et al. 2010. Glutamine treatment attenuates the development of ischaemia/reperfusion injury of the gut'. Eur. J. Pharmacol., 643, 304-15.

Montgomery, H. and Dymock, J. 1961. Colorimetric determination of nitric oxide'. Analyst, 86, 414-17.

Münzel, T.; Daiber, A.; Ullrich, V. and Mülsch, A. 2005. Vascular consequences of endothelial nitric oxide synthase uncoupling for the activity and expression of the soluble guanylyl cyclase and the cGMP-dependent protein kinase'. Arterioscler. Thromb. Vasc. Biol., 25, 1551-57.

Nezu, Y.; Nezu, Y.; Shigihara, K.; Harada, Y.; Yogo, T.; Hara, Y., et al. 2008. Effects of small intestinal ischemia and reperfusion on expression of tumor necrosis factor- $\alpha$ and interleukin-6 messenger RNAs in the jejunum, liver, and lungs of dogs'. Am. J. Vet. Res., 69, 512-18.

Nishikimi, M.; Appaji, N. and Yagi, K. 1972. The occurrence of superoxide anion in the reaction of reduced phenazine methosulfate and molecular oxygen'. Biochem. Biophys. Res. Commun., 46, 849-54.

Ohkawa, H.; Ohishi, N. and Yagi, K. 1979. Assay for lipid peroxides in animal tissues by thiobarbituric acid reaction'. Anal. Biochem., 95, 351-58. 
Ozkan, O. V.; Yuzbasioglu, M. F.; Ciralik, H.; Kurutas, E. B.; Yonden, Z.; Aydin, M., et al. 2009. Resveratrol, a natural antioxidant, attenuates intestinal ischemia/reperfusion injury in rats'. Tohoku J. Exp. Med., 218, 251-8.

Pacher, P. and Hajnóczky, G. 2001. Propagation of the apoptotic signal by mitochondrial waves'. The EMBO journal, 20, 4107-21.

Parks, D. A.; Williams, T. K. and Beckman, J. S. 1988. Conversion of xanthine dehydrogenase to oxidase in ischemic rat intestine: a reevaluation'. Am. J. Physiol., 254, G768-74.

Robin, E.; Guzy, R. D.; Loor, G.; Iwase, H.; Waypa, G. B.; Marks, J. D., et al. 2007. Oxidant stress during simulated ischemia primes cardiomyocytes for cell death during reperfusion'. J. Biol. Chem., 282, 19133-43.

Sambrook, J. and Russell David, W. 1989. Molecular cloning: a laboratory manual. Vol. 3 (Cold spring harbor laboratory press).

Sanchez-Mendoza, M. E.; Cruz-Antonio, L.; Baez, D. A.; Olivares-Corichi, I. M.; RojasMartínez, R.; Martínez-Cabrera, D., et al. 2015. Gastroprotective activity of methyleugenol from Peperomia Hispidula on ethanol-induced gastric lesions in rats'. Int. J. Pharm., 11, 697-704.

Sell, A. B. and Carlini, E. A. 1976. Anesthetic action of methyleugenol and other eugenol derivatives'. Pharmacology, 14, 367-77.

Spiecker, M.; Darius, H.; Kaboth, K.; Hübner, F. and Liao, J. K. 1998. Differential regulation of endothelial cell adhesion molecule expression by nitric oxide donors and antioxidants'. J. Leukoc. Biol., 63, 732-39.

Stefanutti, G.; Pierro, A.; Parkinson, E. J.; Smith, V. V. and Eaton, S. 2008. Moderate hypothermia as a rescue therapy against intestinal ischemia and reperfusion injury in the rat'. Crit. Care Med., 36, 1564-72.

Thurman, J. M. 2007. Triggers of inflammation after renal ischemia/reperfusion'. Clin. Immunol., 123, 7-13.

Van der Heiden, C.; Bais, R.; Gerhardt, W.; Lorentz, K. and Rosalki, S. 1994. Approved recommendation on IFCC methods for the measurement of catalytic concentration of enzymes. Part 8. IFCC method for lactate dehydrogenase'. Eur. J. Clin. Chem. Clin. Biochem., 32, 639-55. 
Vincenti, M.; Behrends, M.; Dang, K.; Park, Y. H.; Hirose, R.; Blasi-Ibanez, A., et al. 2010. Induction of intestinal ischemia reperfusion injury by portal vein outflow occlusion in rats'. J. Gastroenterol., 45, 1103-10.

Xiao, F.; Eppihimer, M. J.; Young, J. A.; Nguyen, K. and Carden, D. L. 1997. Lung neutrophil retention and injury after intestinal ischemia/reperfusion'. Microcirculation, 4, 359-67.

Yamamoto, S.; Tanabe, M.; Wakabayashi, G.; Shimazu, M.; Matsumoto, K. and Kitajima, M. 2001. The role of tumor necrosis factor-alpha and interleukin-1beta in ischemiareperfusion injury of the rat small intestine'. J. Surg. Res., 99, 134-41.

Yao, Y.-M.; Bahrami, S.; Redl, H.; Fuerst, S. and Schlag, G. 1997. IL-6 release after intestinal ischemia/reperfusion in rats is under partial control of TNF'. J. Surg. Res., 70, 21-26.

Yogalakshmi, B.; Viswanathan, P. and Anuradha, C. V. 2010. Investigation of antioxidant, antiinflammatory and DNA-protective properties of eugenol in thioacetamide-induced liver injury in rats'. Toxicology, 268, 204-12.

Zeng, X.; Wang, H.; Xing, X.; Wang, Q. and Li, W. 2016. Dexmedetomidine Protects against Transient Global Cerebral Ischemia/Reperfusion Induced Oxidative Stress and Inflammation in Diabetic Rats'. PLoS One, 11, e0151620.

Zheng, X.; Zheng, X.; Mao, Y.; Cai, J.; Li, Y.; Liu, W., et al. 2009. Hydrogen-rich saline protects against intestinal ischemia/reperfusion injury in rats'. Free Radic. Res., 43, 47884.

Zingarelli, B.; Hake, P. W.; Mangeshkar, P.; O'Connor, M.; Burroughs, T. J.; Piraino, G., et al. 2007. Diverse cardioprotective signaling mechanisms of peroxisome proliferatoractivated receptor-gamma ligands, 15-deoxy-Delta12,14-prostaglandin J2 and ciglitazone, in reperfusion injury: role of nuclear factor-kappaB, heat shock factor 1, and Akt'. Shock, 28, 554-63. 
Table 1. "Primer sequences for GAPDH, IL-6 and TNF- $\alpha$ cDNAs"

\begin{tabular}{cccc}
\hline Gene & Sense 5-3 & Antisense 5-3 & Product \\
& & & size (bp) \\
\hline GAPDH & GTATCGGACGCCTGGTTAC & CTTGCCGTGGGTAGAGTCAT & $\mathbf{1 2 8}$ \\
\hline $\boldsymbol{I L - 6}$ & AGAGGAGACTTCACAGCCGG & ACAGTGCATCATCGCTGTTC & $\mathbf{1 5 7}$ \\
\hline $\boldsymbol{T N F}-\boldsymbol{\alpha}$ & TCGGGTTCCCATAAGTCAG & CTTGGGATTTGATGCTGGT & $\mathbf{2 2 3}$ \\
\hline $\boldsymbol{G A P D H}$, glyceraldehyde-3-phosphate dehydrogenase; $I L-6$, Interleukin $6 ; T N F-\alpha($ Tumor necrosis factor-
\end{tabular}


Table 2: Protective Effect of methyl eugenol on serum LDH, tissue MDA and intestinal antioxidant enzymes following I/R injury.

\begin{tabular}{|c|c|c|c|c|}
\hline Parameters & Sham & ME & $\mathbf{I} / \mathbf{R}$ & $\mathbf{M E}+\mathbf{I} / \mathbf{R}$ \\
\hline Serum LDH (U/L) & $8577.10 \pm 38.46^{a}$ & $8242.11 \pm 35.22^{a}$ & $12913.21 \pm 115.91^{b}$ & $8970.12 \pm 28.38^{a}$ \\
\hline MDA (nmol/g tissue) & $65.38 \pm 2.42^{a}$ & $62.38 \pm 2.42^{a}$ & $91.20 \pm 2.13^{b}$ & $56.66 \pm 1.21^{c}$ \\
\hline GSH (mg/g tissue) & $16.00 \pm 0.85^{a}$ & $17.15 \pm 0.55^{a}$ & $10.48 \pm 0.65^{b}$ & $14.22 \pm 0.49^{a}$ \\
\hline GST (nmol/min/g tissue & $3.47 \pm 0.09^{a}$ & $4.05 \pm 0.01^{a}$ & $1.75 \pm 0.03^{b}$ & $3.26 \pm 0.02^{a}$ \\
\hline SOD (U/g tissue) & $65.27 \pm 0.35^{a}$ & $68.08 \pm 0.43^{a}$ & $35.45 \pm 0.25^{b}$ & $55.56 \pm 0.33^{c}$ \\
\hline CAT (U/min) & $2.75 \pm 0.25^{a}$ & $2.99 \pm 0.53^{a}$ & $1.53 \pm 0.33^{b}$ & $2.49 \pm 0.15^{a}$ \\
\hline NO (nmol/g tissue) & $14.59 \pm 0.41^{a}$ & $13.79 \pm 0.31^{a}$ & $20.98 \pm 0.27^{b}$ & $15.80 \pm 0.49^{a}$ \\
\hline $\begin{array}{l}\text { LDH }=\text { Lactate } \\
\text { Glutathione-S-tra } \\
\text { expressed as mea } \\
(P<0.01) .\end{array}$ & $\begin{array}{l}\text { ehydrogenase; MD } \\
\text { sferase; SOD = supe } \\
\pm \mathrm{SE} ; \mathrm{n}=6 . \text { Letters }\end{array}$ & $\begin{array}{l}\text { = Malondialdehyd } \\
\text { xide dismutase; CA } \\
\text { ot sharing a commor }\end{array}$ & $\begin{array}{l}\mathrm{GSH}=\text { Glutathione } \\
=\text { Catalase; } \mathrm{NO}=\mathrm{Nit}\end{array}$ & $\begin{array}{l}\text { ced; GST = } \\
\text { ide. Data are } \\
\text { ntly different }\end{array}$ \\
\hline
\end{tabular}


Fig 1. Serum tumor necrosis factor- alpha (TNF- $\alpha$ ) concentration in Sham-operated animals, methyl eugenol (ME), Ischemia/Reperfusion (I/R), and I/R animals pretreated with ME $(\mathbf{M E}+\mathbf{I} / \mathbf{R})$. Data are expressed as mean $\pm \mathrm{SE} ; \mathrm{n}=6$. Letters not sharing a common letter superscript are significantly different $(P<0.01)$.

Fig 2. Comparison of methyl eugenol (ME) effect on the expression of tumor necrosis factor- alpha $(T N F-\alpha)$, interlukin-6 (IL-6) and glyceraldehyde-3-phosphate dehydrogenase (GAPDH) in the intestinal tissue by q RT-PCR of Sham, ME, Ischemia/Reperfusion (I/R), and I/R animals pretreated with $\mathrm{ME}(\mathrm{ME}+\mathrm{I} / \mathrm{R})$ after $30 \mathrm{~min}$ ischemia and $60 \mathrm{~min}$ reperfusion. Data are expressed as mean $\pm \mathrm{SE} ; \mathrm{n}=6$. Letters not sharing a common letter superscript are significantly different $(\mathrm{P}<0.01)$.

Fig 3. Immunohistochemical analysis of tumor necrosis factor-alpha (TNF- $\alpha$ ) positive cells (indicated by arrows) in the small intestinal tissues in Sham, Ischemia/Reperfusion (I/R), and I/R animals pretreated with ME (ME+I/R). Expression of TNF- $\alpha$ positive cells in the mucosal layer of small intestine was downregulated in ME + I/R group (D) when compared with Sham (A), ME (B) and I/R groups (C) Magnification=40x. (E) The numbers of TNF- $\alpha$ positive cells detected in the mucosal layer of intestinal small tissues after small $30 \mathrm{~min}$. ischemia and $60 \mathrm{~min}$. reperfusion. Data are expressed as mean $\pm \mathrm{SE} ; \mathrm{n}=6$. Letters not sharing a common letter superscript are significantly different $(P<0.01)$.

Fig 4. Immunohistochemical analysis of Caspase-3positive cells in the small intestinal tissues in Sham, Ischemia/Reperfusion (I/R), and $I / R$ animals pretreated with ME (ME+I/R). Expression of Caspase-3positive cells in the mucosal layer of small intestine was downregulated in ME + I/R group (D) when compared with Sham (A), ME (B) and I/R groups (C) Magnification=40x. (E) The numbers of Caspase-3positive cells detected in the mucosal layer of intestinal small tissues after small $30 \mathrm{~min}$. ischemia and $60 \mathrm{~min}$. reperfusion. 
Data are expressed as mean $\pm \mathrm{SE} ; \mathbf{n}=6$. Letters not sharing a common letter superscript are significantly different $(P<\mathbf{0 . 0 1})$.

Fig 5. Histological observation of the intestinal tissue in sham, Methyl Eugnol (ME), Ischemia/Reperfusion (I/R), and $I / R$ animals pretreated with ME (ME+I/R). Photomicrographs of the intestinal tissue stained by the hematoxylin and eosin (100X). Normal histological features of intestinal tissue in (A) Sham and (B) ME groups. (C) I/R: showing necrosis of the intestinal villi (small arrow), inflammatory cells infiltration (large arrow) and hemorrhage in lamina propria (arrow head). (D) ME + I/R: the architecture of the villi are nearly preserved. (E) Chiu scoring system of histopathological features of intestinal injury. The bars represent mean $\pm \mathrm{SE}$ of five digital images per animal in each group. $(P<0.01)$.

Fig 6. DNA fragmentation showing laddered and smeared DNA isolated from the intestine of rats in Ischemia/Reperfusion group (I/R) compared with slight smear DNA in I/R animals pretreated with ME group $(\mathrm{ME}+\mathrm{I} / \mathrm{R})$ and intact DNA in the sham and Methyl Eugenol (ME) group 


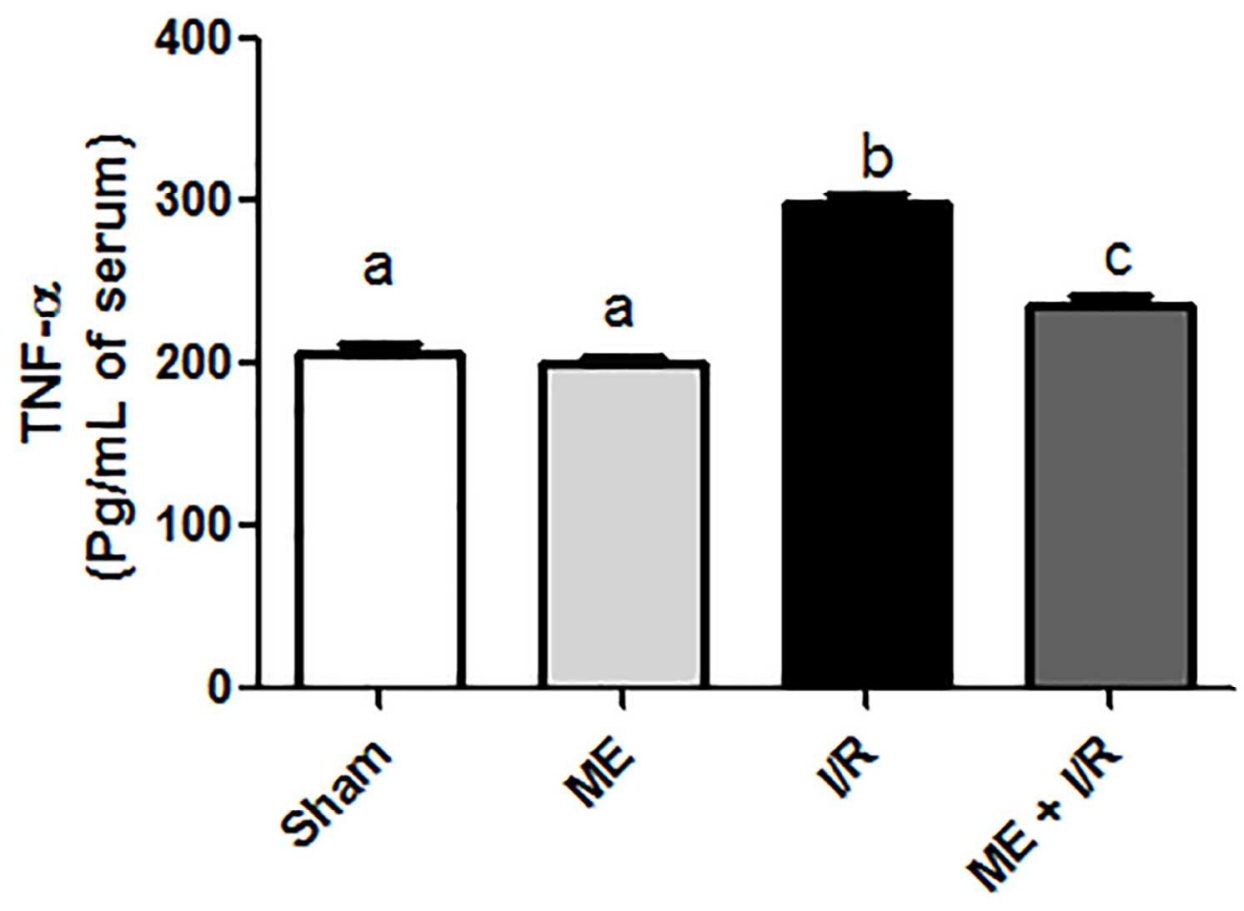

Fig 1. Serum tumor necrosis factor- alpha (TNF- a) concentration in Sham-operated animals, methyl eugenol (ME), Ischemia/Reperfusion (I/R), and I/R animals pretreated with ME (ME+I/R). Data are expressed as mean $\pm S E ; n=6$. Letters not sharing a common letter superscript are significantly different $(P<0.01)$.

$106 \times 80 \mathrm{~mm}(300 \times 300 \mathrm{DPI})$ 

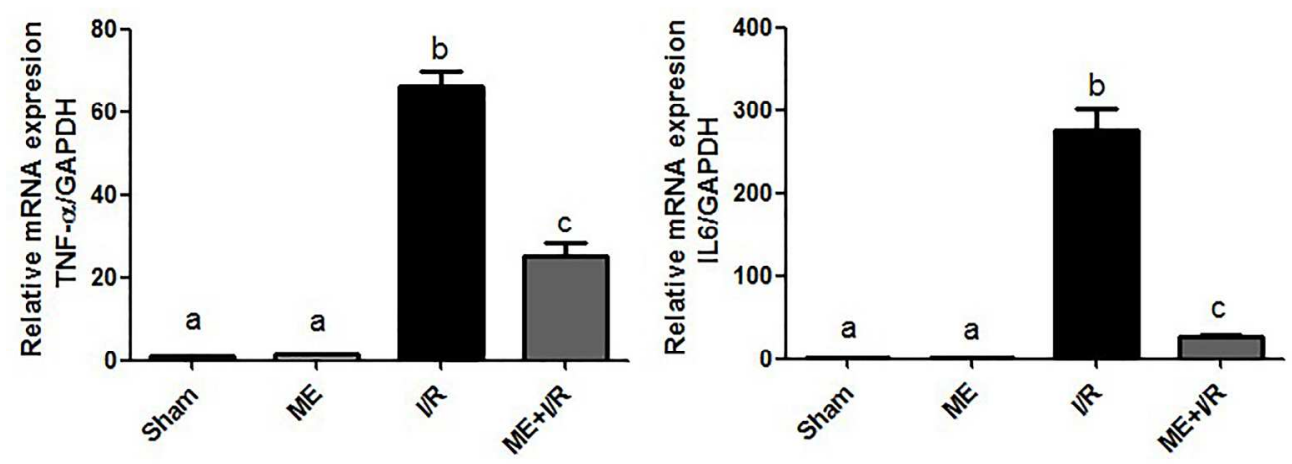

Fig 2. Comparison of methyl eugenol (ME) effect on the expression of tumor necrosis factor- alpha (TNF-a), interlukin-6 (IL-6) and glyceraldehyde-3-phosphate dehydrogenase (GAPDH) in the intestinal tissue by q RTPCR of Sham, ME, Ischemia/Reperfusion (I/R), and I/R animals pretreated with ME (ME+I/R) after 30 min ischemia and 60 min reperfusion. Data are expressed as mean $\pm S E ; n=6$. Letters not sharing a common letter superscript are significantly different $(P<0.01)$.

$207 \times 78 \mathrm{~mm}(300 \times 300$ DPI) 

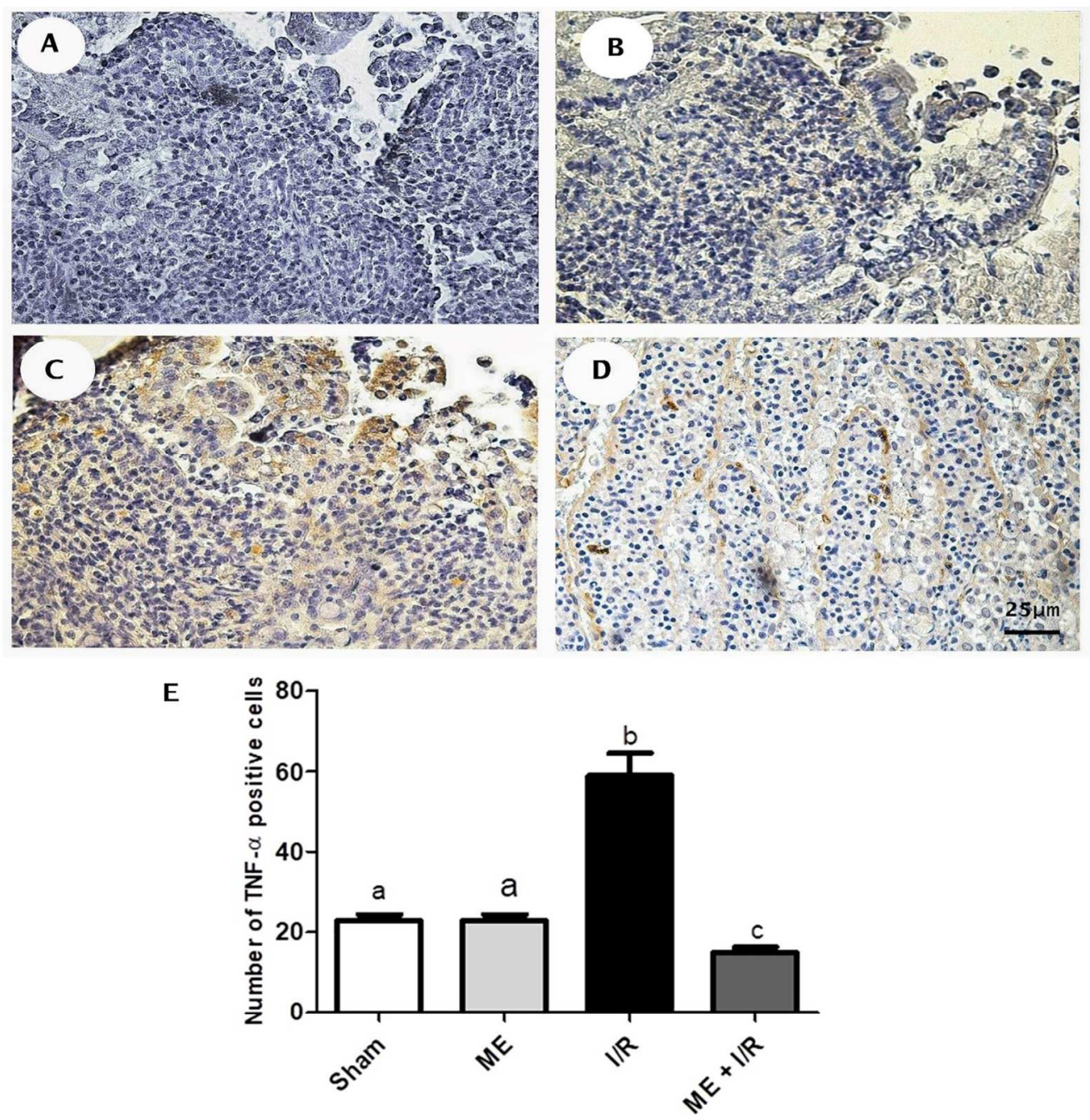

Fig 3. Immunohistochemical analysis of tumor necrosis factor-alpha (TNF-a) positive cells (indicated by arrows) in the small intestinal tissues in Sham, Ischemia/Reperfusion (I/R), and I/R animals pretreated with ME (ME+I/R). Expression of TNF-a positive cells in the mucosal layer of small intestine was downregulated in ME + I/R group (D) when compared with Sham (A), ME (B) and I/R groups (C) Magnification=40x. (E) The numbers of TNF-a positive cells detected in the mucosal layer of intestinal small tissues after small 30 min. ischemia and 60 min. reperfusion. Data are expressed as mean $\pm S E ; n=6$. Letters not sharing a common letter superscript are significantly different $(P<0.01)$.

$148 \times 153 \mathrm{~mm}(300 \times 300 \mathrm{DPI})$ 

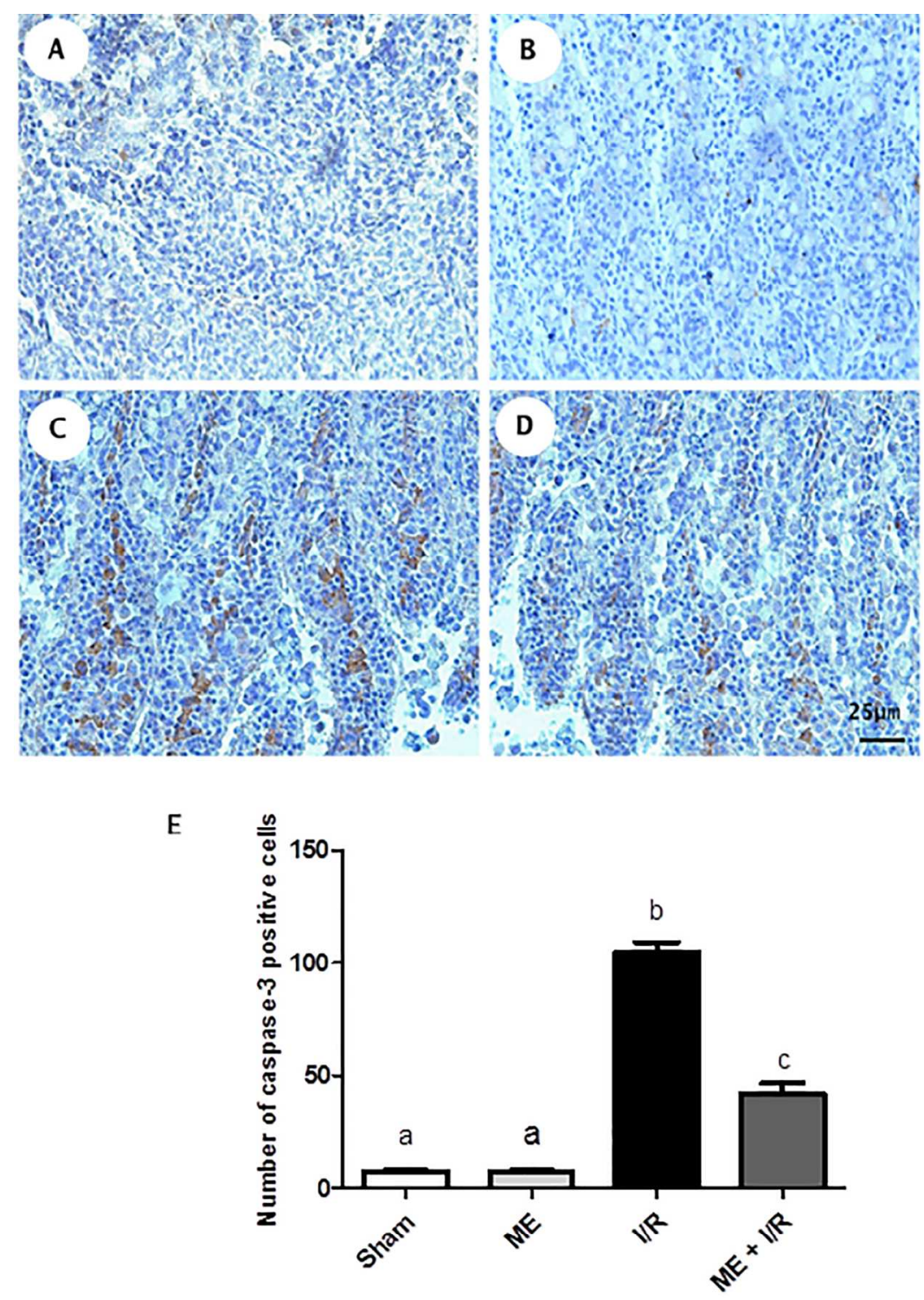

Fig 4. Immunohistochemical analysis of Caspase-3positive cells in the small intestinal tissues in Sham, Ischemia/Reperfusion (I/R), and I/R animals pretreated with ME (ME+I/R). Expression of Caspase-3positive cells in the mucosal layer of small intestine was downregulated in ME + I/R group (D) when compared with

Sham (A), ME (B) and I/R groups (C) Magnification=40x. (E) The numbers of Caspase-3positive cells detected in the mucosal layer of intestinal small tissues after small $30 \mathrm{~min}$. ischemia and $60 \mathrm{~min}$. reperfusion. Data are expressed as mean $\pm S E ; n=6$. Letters not sharing a common letter superscript are significantly different $(P<0.01)$.

$129 \times 192 \mathrm{~mm}(300 \times 300 \mathrm{DPI})$ 

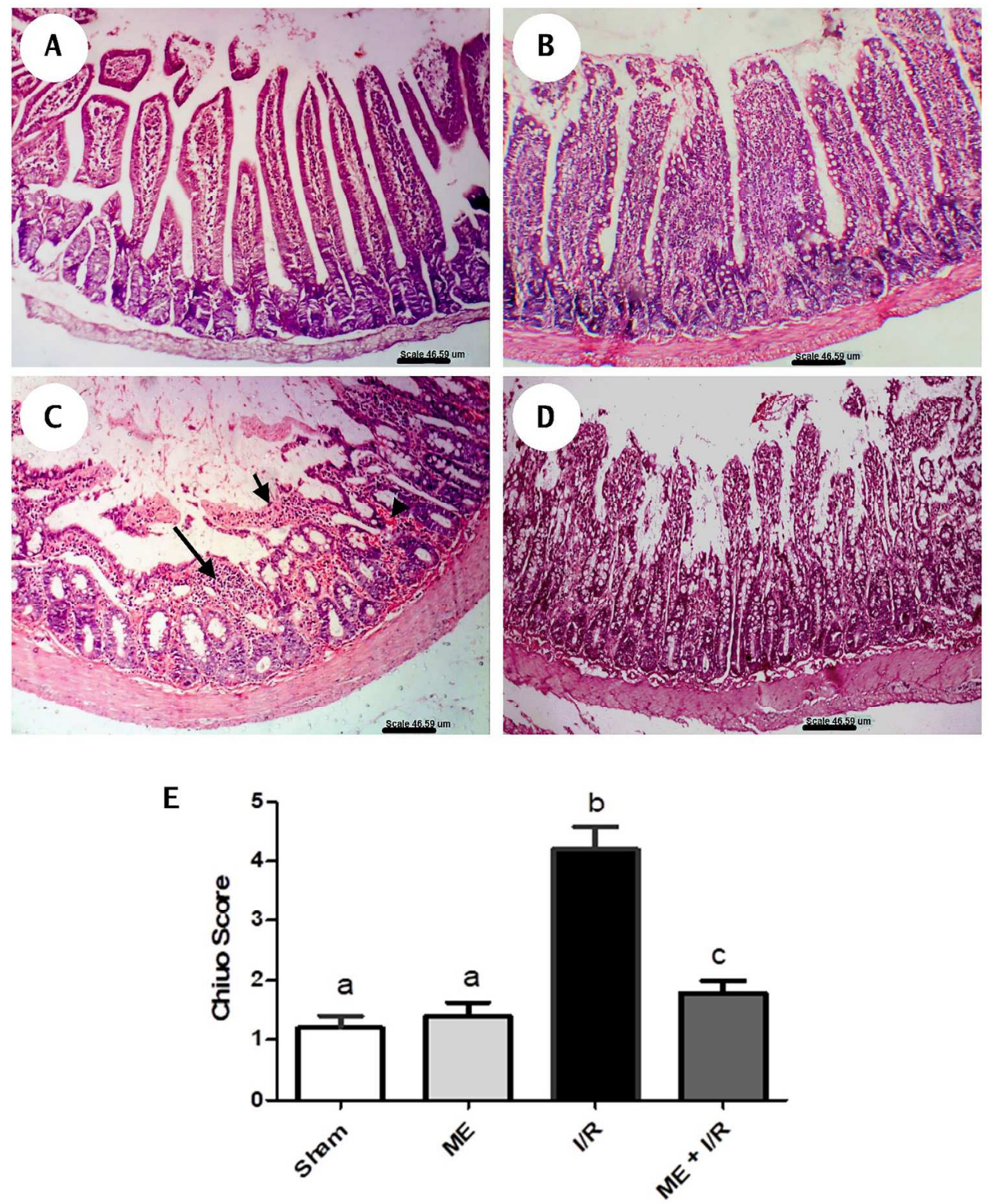

Fig 5. Histological observation of the intestinal tissue in sham, Methyl Eugnol (ME), Ischemia/Reperfusion $(I / R)$, and I/R animals pretreated with $M E(M E+I / R)$. Photomicrographs of the intestinal tissue stained by the hematoxylin and eosin (100X). Normal histological features of intestinal tissue in (A) Sham and (B) ME groups. (C) I/R: showing necrosis of the intestinal villi (small arrow), inflammatory cells infiltration (large arrow) and hemorrhage in lamina propria (arrow head). (D) ME + I/R: the architecture of the villi are nearly preserved. (E) Chiu scoring system of histopathological features of intestinal injury. The bars represent mean \pm SE of five digital images per animal in each group. $(P<0.01)$.

$$
165 \times 198 \mathrm{~mm}(300 \times 300 \text { DPI) }
$$




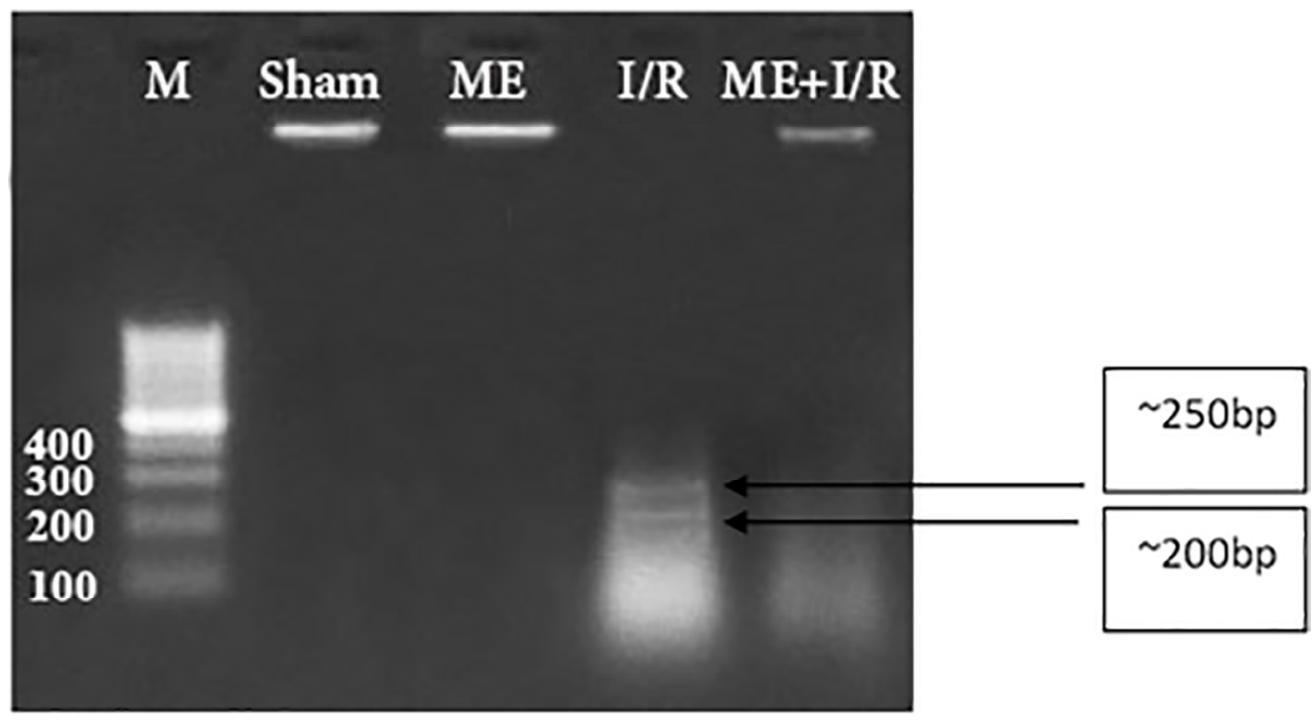

Fig 6. DNA fragmentation showing laddered and smeared DNA isolated from the intestine of rats in Ischemia/Reperfusion group (I/R) compared with slight smear DNA in I/R animals pretreated with ME group $(\mathrm{ME}+\mathrm{I} / \mathrm{R})$ and intact DNA in the sham and Methyl Eugenol (ME) groups

$112 \times 61 \mathrm{~mm}(300 \times 300 \mathrm{DPI})$ 